\title{
Educational Reform in the Kingdom of Saudi Arabia: Tatweer Schools as a Unit of Development
}

\author{
Rfah Hadi Alyami \\ Institute of Education: University of Reading, United Kingdom
}

\begin{abstract}
Globalization has a significant influence on the educational system of Saudi Arabia. Therefore, this study is the first to investigate the impact of educational policy development on practice within Tatweer Schools in this country, to seek in which aspects they are innovative and to examine the level of autonomy. This study is important in terms of timing, as the Tatweer Programme is a new policy innovation. It is hoped that the research will provide policy-makers with insights into actual practice and the real-life context within such schools. This preliminary study uses qualitative data obtained in semi-structured interviews, focus groups and documentary analysis. The majority of the participants have a positive attitude about the Tatweer Programmes. It is a major shift of Saudi educational policy; moving from centralization to decentralization, from focusing on the individual to team learning; from being isolated schools to be open schools and having a partnership with society. Despite these significant developments, however, the level of students' achievement has not been changed.
\end{abstract}

\section{Introduction}

In recent decades, globalization has had a significant effect on education in a great number of countries. Masri [1] argues "it can be taken for granted that good quality education at all levels and in all fields, through formal and non-formal systems, is a major tool in dealing with the challenges of globalization, utilizing its potentials and avoiding its pitfalls" (p.142). As a result, many countries have sought to reform their educational system to address perceived weaknesses in their global standing. This paper gives an example of Saudi educational reform.

In the Kingdom of Saudi Arabia (KSA), King Abdullah bin Abdul-Aziz Project for Public Education Development ${ }^{1}$ was established to reform Saudi educational system in 2007. This project initially sat up 25 girls' secondary schools and 25 boys' secondary schools (Tatweer ${ }^{2}$ Schools: smart

\footnotetext{
${ }^{1}$ This organization will be called Tatweer Project in this paper.

${ }^{2}$ Tatweer Arabic word, it means development.
}

schools) across 25 provinces in Saudi Arabia, and these were in the first phase of the project. The philosophy that guides education development in Saudi Arabia from the Project vision was to focus on school development, and this was because of the school as a unit of the educational system, where efforts of reform and improvement of the education system can be made [2].

The second phase of this project called School Development Model (Tatweer Schools: selfevaluation schools). Tatweer Schools consider as innovative in terms of embedded theories concerned with Professional Learning Community, selfplanning and evaluation and professional development [2].

\section{Research Rationale}

\subsection{Smart Model (Tatweer schools: Phase One)}

Tatweer School in the first phase offers new option for schools to change its role from traditional school to smart learning school that shifted from being only a place of education to be educational environment, for learning that includes modern educational technology with activated educational leader and qualified teachers, who assist to facilitate and direct learning processes with using safe and appropriate methods [2].

However, this model has been considered as a costly model to generalize it to cover all Saudi public schools. As a result, they modified the pilot scheme of such project and have planned to create a new model to be in the phase two.

\subsection{School development model (Tatweer Schools: Phase Two)}

Implementing this model started in 2011, schools have to be self-evaluation and planning schools. These schools have to conduct the project from their potential instead of providing them with high advanced technology as in phase one. The school development model is based on a set of principles [2]: 
Excellence for all: every student deserves to excel, and reach his maximum capacity. Each teacher also deserves to be excellent and develops in his career in order to efficiently perform his role in the school.

Commitment from everyone: all school employees are committed to school values, and believe in its mission, dedicated to achieve its objectives, and follow policies and regulations.

Accountability for all: each one in the school is responsible for his performance, and that the school employs reinforcement (positive and negative) according to the quality of performance for all school employees.

Professionalism from everyone: school employee's practices are driven from educational reliable knowledge and that practices and decisions are based on scientific reference frames. Transparency and clarity by everyone: transparency and clarity in showing results and performance levels, and display of negatives and positives in the school's performance to stakeholders.

In any innovative programme of school reform, however, questions have to be asked:

"Was the innovation ever really implemented? ...Once implemented, did the innovation maintain its integrity and purpose? ... Have students been positively and significantly affected? ... Did the innovation become integrated into the school's mission and organization? ... Did successful programmes continue to exit? ... Was it possible to transfer the innovation from one school context to another?" [3]

Change is conceived as an intervention in the processes of meaning making and understanding, which is then translated into everyday practice. Reform programmes in sense making organisations are initiated through collaborative work on the simultaneous construction of new ways of doing things and new ways of talking about what is happening. If a programme to encourage creativity was introduced to a school as a sense-making collective, then an evaluation would show how the language, metaphor and symbolic systems of the school were changed, how dramas of change were enacted and played out, and how narratives about the school were transformed (p.22)

While the Kingdom of Saudi Arabia has implemented a large number of educational reforms, the empirical evidence base linked to the evaluation and impact of these is relatively sparse. This study, therefore, aims to fill this gap exploring the impact of educational policy development on practice within Tatweer Schools, to seek in which aspects they are innovative and to examine the level of autonomy.
This study is a preliminary study undertaken as part of a large research in this area.

\section{Policy of Education in Saudi Arabia}

Saudi Arabia is a nation where the Islamic Code of life is being practiced in all aspects, from personal habits to education system. The government also keeps in mind these codes before setting any sort of policy for the nation. Children are required to attend 6 years of primary, 3 years of intermediate and 3 years of secondary schooling in order to complete their education. All these levels are free of charge for the students of this nation as stated by the government [4].

After the event of Sept 11, it was required that the policies regarding education must be altered in Saudi Arabia. Their curriculum must not consist of any subject that stresses upon extremism [5]. Thorough evaluation of the curriculum has been demanded by officials within and outside the nation in order to refrain from introducing such concepts in the classroom. King Abdullah has demanded the implementation of the Tatweer project which requires improvement within the educational system and managing the issues present in the curriculum of the schools, which are under his region [6].

In Saudi Arabia and before 1960, women were only provided with informal education. The girls were required to be educated at home as per their culture. The women cannot be negatively impacted by society, which is why they were kept at home mostly. At this point of time, different stories have been stated for girl's education. Some of the individuals sent their daughters only to the school of $K u t a b$, where they would learn how to recite the holy Quran. Many sent their daughter to learn about religion as well as other subject matters so they may be able to implement this knowledge as an efficient wife, mother or daughter. These women were not allowed to complete their higher education. The rest and a few of the individuals allowed their daughters to not only receive primary and intermediate education but they were also allowed to attend college. Religious opposition existed upon all these aspects and also the culture of the society found it strange for women to attend schools or colleges [7, 8].

The people, politics and specifically the ulama (clerics) show much resistance if any change in the education system. The future of the country needs to be kept in mind before making any changes to the curriculum of the schools. This is a political concern and affects the national identity which is why it form a strong connection between the people, ulama and the government [5]. However, based on global requirements, Saudi Arabia has introduced many changes as part of its educational policy. 


\section{School management in the KSA}

Headship in Saudi schools is gendered, where the male leader has to manage boys' schools and the female has to manage girls' schools. The culture associated with religion is one component that represents the education culture in Saudi Arabia [3]. Head teacher is the person who is responsible for the management of the educational processes within the school, and to enhance its effectiveness. Perhaps the most important factor to develop the school administration is to grant the head teacher wider power. This is to ensure freedom of action and independence, which to some extent will enable them to achieve the desired goals.

Many studies have illustrated that one of the most important field problems that head teachers face in the Kingdom of Saudi Arabia is a few power granted to head teachers [6, 9-14].

A study by Alsayqh [9] reveals the insights about power of head teachers in the decision-making process in regard to educational regulations. She found that the authority of the Department of Education is the most influential factor on the powers of the head teachers. The researcher recommended that it would be worth granting head teachers more power, which is comparable to the responsibilities as well as maintaining professional development. Another study by Alzaidi [15] shows that there is a lack of school autonomy, because of the centralized system, which characterized by a weak authority has been given to head teachers in the Saudi educational system. He presents some factors that lead to dissatisfaction; the most important factor according to the participants is the lack of authority to undertake responsibilities.

Alshihri [12] stresses the importance of parity between the authority and responsibility, where it is important to balance between the responsibilities and the amount of the authority that help to conduct the responsibilities. If the head teacher in charge of the responsibilities, he or she must be given an appropriate power to undertake these responsibilities.

Alsahli [11] points out that each employee who has responsibility should be given power to achieve the goal of his or her job. It is expected that the employee would perform duties in the best way when authority linked to responsibility. The authority and responsibility are two opposite factors. The balance between them leads to resolve the undertaking function. Asfoor [16] supports this notion; he claims that the responsibility needs to be matched with sufficient authority. As delegating, any task must be paired with delegating an appropriate authority in practice; the power has to be placed in the hands of the employee or the principal in order to achieve specific goals.

A study prepared by Muzm [10] aimed to identify the extent of the level of power with the responsibilities of head teachers. The study found that there were too many responsibilities received from the regulations and circulars. These responsibilities required review and reconsideration to enable school administrators to do better; the granted powers to head teachers were not appropriate with their responsibilities. In addition, Mathis [6] in her study claims that in order to develop the system and achieve educational reform, it is essential to regard the role of leadership as a significant aspect that leads to changes in any organization. She concludes that the head teachers in Saudi Arabia do not have enough autonomy to act or to make the decision; they describe their role as a manager rather than being a leader.

Despite these difficulties, however, Saudi educational system has an intention to shift its policy to decentralize towards significant autonomy within schools, which requests from head teachers more knowledge of their responsibility [2]. Albahiri [17] argues that:

It is noteworthy that the Ministry of Education has not revised and updated its general policies and goals since 1970 although it has changed and updated many aspects of its system, such as curricula, plans for teachers' preparation and qualification, study plans, etc. Moreover, the rapid changes worldwide in all aspects of education require rapid revision and change in all educational systems, and this is what the Saudi education system has been trying to do but without official long-term goals (p.23).

Elmore and McLaughlin [18] reveal that to enable reforms in a large-scale plan, dialogue must be considered among three dimensions: policy, administration and practice where policy can make an effective administration and practice by setting the conditions. The problem as Elmore and Wallin view is that it is difficult to predetermine the way that decisions would make.

To identify the reality of leadership in Saudi educational institutions from the top of the pyramid (Ministry of Education) to the bottom of the pyramid (School) in making decisions it must knowing the pattern of regulation which is applied by the departments of these educational institutions. As a result of widening the geographical area of the Kingdom and having a massive number of schools, the Ministry of Education as the central supervisor upon education find it difficult to supervise these schools, so the ministry tended to create departments of education in Saudi districts to be responsible of supervision of schools in all administrative and technical aspects [19]. Management scholars assert that administrative decentralization in any organization would be significant in the following 
cases: If the number of decisions that are taken at the lowest administrative levels is increased, if the importance of the decisions that are taken at the lowest administrative levels is becoming great, if the number of jobs that are affected by decisions taken in lower administrative levels is increased, if the number of audits for decisions in lower administrative levels is reduced [20]. These dimensions are not the case in the Saudi educational system, where these factors can be held at the top of the pyramid.

The centralization in administration means dominance the senior management upon decisionmaking power. On the other hand, decentralization means distribute the power to all administration levels, despite the theoretical division of centralization and decentralized; the real life does not absolutely apply centralized or decentralized in all institutions whether at the level of the school administration, the department of education or Ministry of education. Accordingly, there is a degree of central authority as well as part of decentralized authority delegated to the following administrative levels to achieve the objectives of the institution [12]

\section{Methodology}

This study is a qualitative one, and it uses qualitative methods: focus groups, semi-structured interviews and documentary analysis. In this paper, the constructionism dimensions are adopted, which can allow a better understanding of the experiences of administrators and practitioners of the Tatweer Schools' system in Saudi context among the perceptions of Tatweer Schools' actors. The study has adopted interpretivism as an epistemological paradigm. The variation will be life-changing phenomenon within Tatweer Schools, where "Different perspectives about such things as truth and the nature of reality constitute paradigms or worldviews based on alternative epistemologies and ontologies. People viewing qualitative findings through different paradigmatic lenses will react differently" [21].

Main questions themes of this preliminary study:

- The role and practices of head teacher, educational experts and the members of Tatweer Units.

- The differences between Tatweer Schools and no Tatweer schools.

- Identify how autonomy is thought to influence school effectiveness.

- Identify the degree of innovation taking place in Tatweer schools.

- The difficulties encountered in conducting such programmes at schools.

\subsection{Interview}

In this preliminary study, eight participants were interviewed: five head teachers, one deputy (ex-head teacher), one educational expert and one Tatweer Unit's members. These interviews were in three cities: Riyadh, Alqassem and Jeddah. The interviews were conducted in Arabic and were recorded after obtaining permissions from interviewees. The interviews were transcribed in Arabic text. Following transcription, I coded the themes manually and then summarized them for each interview.

Table 1. Overview of participants' information and the interviews

\begin{tabular}{|c|c|c|c|c|c|c|}
\hline Name & Position & Date & $\begin{array}{l}\text { Years } \\
\text { in } \\
\text { educat } \\
\text { ion }\end{array}$ & Duration & $\begin{array}{l}\text { Qualificatio } \\
\text { n }\end{array}$ & City \\
\hline Reem & $\begin{array}{l}\text { Head } \\
\text { teacher }\end{array}$ & $\begin{array}{l}7-5- \\
2012\end{array}$ & $\begin{array}{l}12 \\
\text { years }\end{array}$ & $\begin{array}{l}45 \\
\text { minutes }\end{array}$ & $\begin{array}{l}\text { Bachelor's } \\
\text { degree in } \\
\text { English }\end{array}$ & Riyadh \\
\hline Nora & $\begin{array}{l}\text { Deputy of } \\
\text { head } \\
\text { teacher }\end{array}$ & $\begin{array}{l}7-5- \\
2012\end{array}$ & $\begin{array}{l}29 \\
\text { years }\end{array}$ & One hour & $\begin{array}{l}\text { Bachelor's } \\
\text { degree in } \\
\text { Geography }\end{array}$ & Riyadh \\
\hline Farah & $\begin{array}{l}\text { Head } \\
\text { teacher }\end{array}$ & $\begin{array}{l}8-5- \\
2012\end{array}$ & $\begin{array}{l}16 \\
\text { years }\end{array}$ & 3 hours & $\begin{array}{l}\text { Bachelor's } \\
\text { degree in } \\
\text { microbiolog } \\
\text { y }\end{array}$ & Riyadh \\
\hline Lubna & $\begin{array}{l}\text { Head } \\
\text { teacher }\end{array}$ & $\begin{array}{l}13-5- \\
2012\end{array}$ & $\begin{array}{l}17 \\
\text { years }\end{array}$ & 3 hours & $\begin{array}{l}\text { Bachelor's } \\
\text { degree in } \\
\text { Maths }\end{array}$ & Alqasseem \\
\hline Hind & $\begin{array}{l}\text { Education } \\
\text { al expert }\end{array}$ & $\begin{array}{l}14-5- \\
2012\end{array}$ & $\begin{array}{l}25 \\
\text { years }\end{array}$ & $\begin{array}{l}50 \\
\text { minutes }\end{array}$ & $\begin{array}{l}\text { Bachelor's } \\
\text { degree in } \\
\text { English }\end{array}$ & Riyadh \\
\hline Hana & $\begin{array}{l}\text { Head } \\
\text { teacher }\end{array}$ & $\begin{array}{l}15-5- \\
2012\end{array}$ & $\begin{array}{l}29 \\
\text { years }\end{array}$ & $\begin{array}{l}\text { One hour } \\
\text { and } 15 \\
\text { minutes }\end{array}$ & $\begin{array}{l}\text { Bachelor's } \\
\text { degree in } \\
\text { media }\end{array}$ & Riyadh \\
\hline Rana & $\begin{array}{l}\text { Head } \\
\text { teacher }\end{array}$ & $\begin{array}{l}21-5- \\
2012\end{array}$ & $\begin{array}{l}31 \\
\text { years }\end{array}$ & $\begin{array}{l}\text { One } \\
\text { hours }\end{array}$ & $\begin{array}{l}\text { Bachelor's } \\
\text { degree in } \\
\text { English }\end{array}$ & Jeddah \\
\hline Suha & $\begin{array}{l}\text { Tatweer } \\
\text { unit's } \\
\text { member }\end{array}$ & $\begin{array}{l}23-5- \\
2012\end{array}$ & $\begin{array}{l}25 \\
\text { years }\end{array}$ & $\begin{array}{l}40 \\
\text { minutes }\end{array}$ & $\begin{array}{l}\text { Bachelor's } \\
\text { degree in } \\
\text { Geography }\end{array}$ & Jeddah \\
\hline
\end{tabular}

\subsection{Focus group}

My plan was to interview three focus groups in three cities; however, upon arrival at the venue of Tatweer Unit in Jeddah I found that the whole group was busy. Unfortunately, only one member of the group was willing to do the interview. However, I interviewed two groups in two cities: Riyadh, the capital of Saudi Arabia and Alqasseem. 
Table 2. Overview of focus groups' information

\begin{tabular}{|c|c|c|c|c|}
\hline Ite & Date & $\begin{array}{l}\text { Members' } \\
\text { number }\end{array}$ & City & $\begin{array}{l}\text { Length of } \\
\text { interviewing }\end{array}$ \\
\hline 1 & $12-5-2012$ & 6 & Alqasseem & 120 minutes \\
\hline 2 & $19-5-2012$ & 4 & Riyadh & 80 minutes \\
\hline
\end{tabular}

\section{Ethical considerations}

At an early step of research project preparations, it is essential to think about ethical issues that might arise from conducting the study [22]. What is vital is to avoid harming participants, to be not deceitful, to give them informed consent and to avoid privacy invasion [23]. For ethical considerations, the first step to be taken is to review the application following the procedures of the University of Reading Ethics Committee to give a favourable ethical opinion for conducting this research. Moreover, approval was granted by the Ministry of Education to access Tatweer schools before conducting this study. In addition, I ensured that all information and participants are kept strictly confidential and I made clear that participation is voluntary and that the participants can withdraw in any time when they want. I also kept the data anonymous, where I made names for them.

\section{Findings}

Five themes have been identified after analyzing the data. These themes helped to answer the main question: what is the impact of educational policy development on practice within Tatweer Schools. These themes are: Innovation; Autonomy; Tatweer Schools and Non-Tatweer Schools; Tatweer Programme one and two; and the Difficulties.

\subsection{Innovation}

According to the participants that innovation could be seen in different levels:

- School level: in Tatweer Schools innovation could be seen in technology, smart classes (in phase one), the implementation of projects and the use of Intel program and projects in learning. There were also intensive training courses for the head teachers and teachers, which lead to professional development and helped to enhance schools' capacity. The programme gave schools internal capacity gradually, in order to create autonomous schools. These schools can be able to solve its problem and build its programme according to its mission and goals.

- Students' level: Many students have won various national and international awards. In addition, students have acquired the skills needed to conduct their own research. Students have gained self-confidence, self-reliant and communication skills. Learners also are looking for information rather than receive it. The enterprise and the ability to express opinion have been promoted at students. In addition, they reach a high level of attainment and ability to debate. Students in these schools learn by doing research. Many academic trips have been held for students; however, the level of students' achievement has not been changed as the participants reported. This finding was unexpected and suggests that it is helpful using the value-added tool, which measure students' achievement in order to assess the impact of the change on students' progresses.

"This programme is very useful. It takes all time of students.... Some parents come to me and say God bless you, our children become busy of doing their homework and doing research, our children do not have much time to think in other things... one of the pretty thing of this programme is that the wrong behavior is reduced to $80-90 \%$ because they are always busy and may be this programme gave them self-confidence, gravity and promoting their thinking" (Lubna, HT, p.38, 13-5-2012)

\subsection{Autonomy}

The freedom: This programme gave head teachers a broad area of autonomy in which to do their best; most reported no restrictions. The head teachers reported that their task became easier as a result of working with teams. The head teachers involved others in decision-making. Teachers had more autonomy in the way that they evaluated and prompted students' skills. Additionally, Tatweer Schools' members reported that they have acquired autonomy in their decisions.

Nature of work: The work ethos within these schools became established and professional. "Excellence Team" played the most important role in decision-making. These schools also opened their doors to train other schools in certain skills, such as co-operative learning and using technology in teaching. In Tatweer School, autonomy associated with self-evaluation of the school's performance. In addition, each Tatweer School built its plans by itself, based on its own needs. Moreover, Tatweer Schools had a new agenda concerned with promoting partnership with community.

As Altrichter [24] argues 'Change' may be used to argue for more autonomy in order to allow and enhance self-management of schools or for stricter central surveillance, accreditation and evaluation, or for both; it may be used to argue for more room for market forces or for more parent participation in the governance of schools". It has also been stressed by Fidler and Edwards [25] that self-assessment is the centre of school improvement. 
Head teachers found themselves free to be creative and innovative as one of them reports that: "The role of the head teacher was inspector and her task was documentary and field, but now with Tatweer Programme her task is becoming creative, developing, schematic and leading the team work" (Hana, HT, p.88, 15-5-2012, interview).

The results of the study did not show any significant increase in the financial autonomy, which would help the school to undertake its programmes. It did not also show any freedom in hiring and firing staff. This finding can be explained by the need to consider many factors to implement fiscal and appointment autonomy within schools, for example, taken into account the culture, people trust, and corruption level. These factors could help to enhance the freedom in fiscal and appointment delegation.

\subsection{Tatweer Schools and non-Tatweer Schools}

The Tatweer Schools are different from nonTatweer Schools in the following aspects:

The autonomy: The Tatweer programmes gave the head teacher more autonomy to manage the school, to achieve her school's vision and purposes as well as give more autonomy in decision-making inside school.

The technology: In Tatweer Schools there are advanced technological equipment especially in Tatweer Smart schools.

The Decision- making: In Tatweer Schools, the decision has been made in team. Every single person from the teacher to the student involve in decisionmaking as well as parents and the society.

The professional development: Teachers and head teachers have had intensive trainings to gain a high level of qualifications.

The plan: These schools have done selfevaluation as one step of building its plan for the following year. The school also builds its plan based on its needs whereas in non-Tatweer Schools, they receive their plan from the ministry of education.

The pedagogy: Tatweer Schools are different than other schools in the way they teach.

These differences can be summarized by saying that Saudi educational system tends to transform its schools from centralized schools to semidecentralized schools. It gives Tatweer Schools more autonomy in their decision-making and more freedom in the way they manage and teach.

"The distinctive of the programme is that it seeks to provide an autonomous school, which can perform self-evaluation and planning by itself, like a small ministry... It also aims to create different models of Tatweer Schools" (Salma, TU, p.21, 12-5-2012, focus group).

\subsection{Tatweer programme one and two}

The differences between Programme one and two can be distinguished in the following elements:

The supervision: A considerable difference is that in phase two there is a Tatweer Unit, which contains nine members. These members work in team and support Tatweer Schools, but in phase one there was one member called educational expert who supported and visited Tatweer School weekly.

The organization: Tatweer Schools were connecting with the Tatweer Project directly, so it is believed that when there was a desire goal to expand schools in a big country such as Saudi Arabia, the education system had to be decentralized. Therefore, programme two sat up seven units in seven districts at the beginning to support Tatweer Schools instead of Tatweer Project.

The cost: Programme one was extremely costly; accordingly, programme two was established as an amendment of programme one. In the programme two, schools were not supplied with advanced technology as in programme one. Officials realized that applying ideal technology at schools would cost a huge amount of money, which was one target of programme one. Therefore, Tatweer Project modified programme two to be, more pragmatic. Namely, programme two has focus on internal capacity where schools will be able to manage itself.

"The difference between Tatweer Programme in phase one and two is that the school in phase one was like a small educational directorate; there were sections, units and departments and every single member had her profile, but in phase two the work runs by the team, it becomes better in terms of being cooperated and interdependent. Now, the team member is sharing each other in school's mission, targets and planning (Noon, TU, p.30, 12-5-2012, focus group). The sense of responsibility is becoming a collective sense rather than individual sense because the school's matter is becoming an important notion for every single person (Joana, TU, p.30, 12-5-2012, focus group). We are also as Tatweer Unit members are become one team" (Huda, TU, p.30, 12-5-2012, focus group). This finding compatible with the previous planned organization of the Tatweer system that has been sat by Tatweer Project the following diagrams by this Project explain this finding. 
Tatweer School system programme one 2007

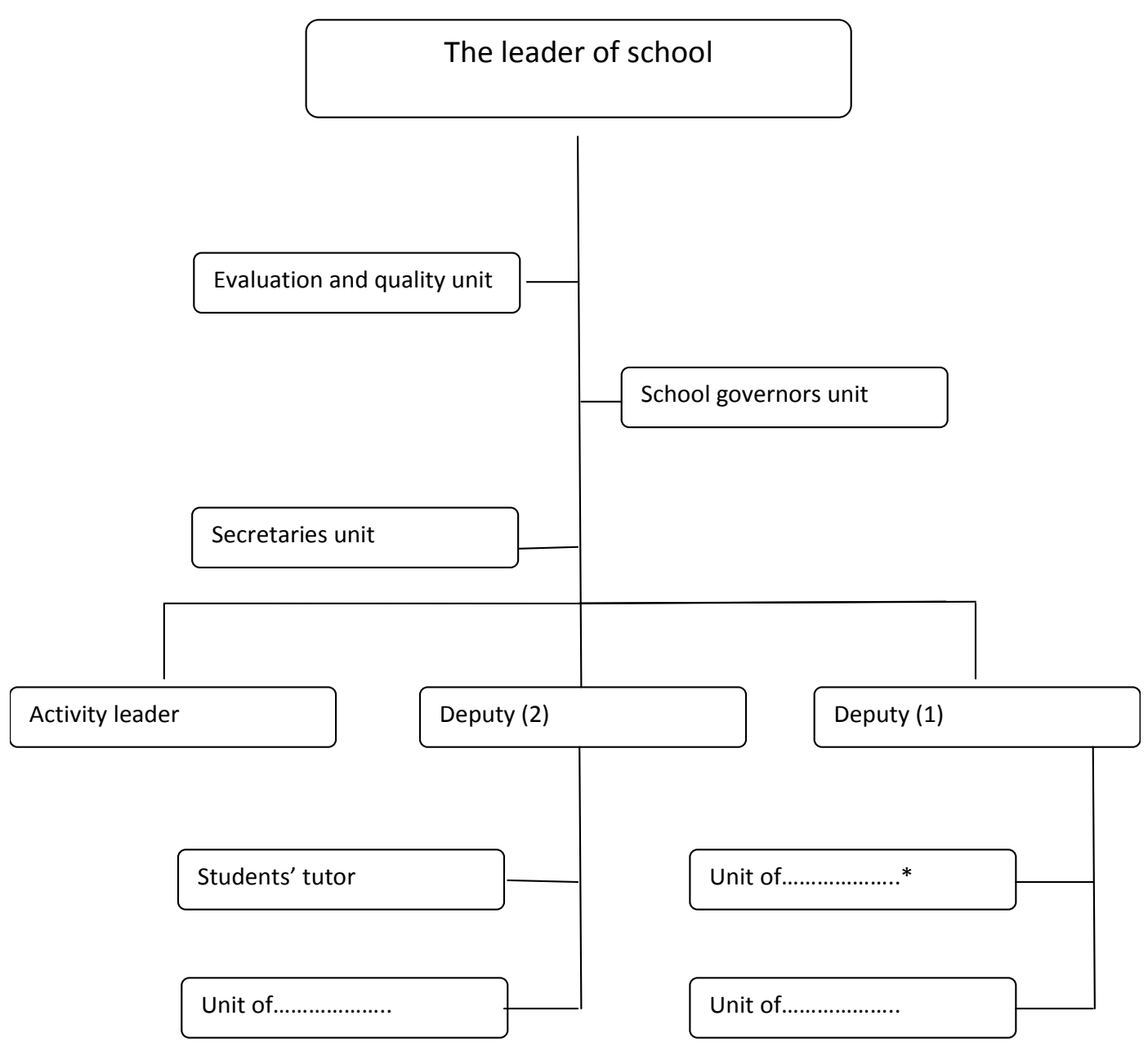

* The leader has freedom to choose any certain unit to meet the school needs 


\section{Tastweer School system programme two 2011}

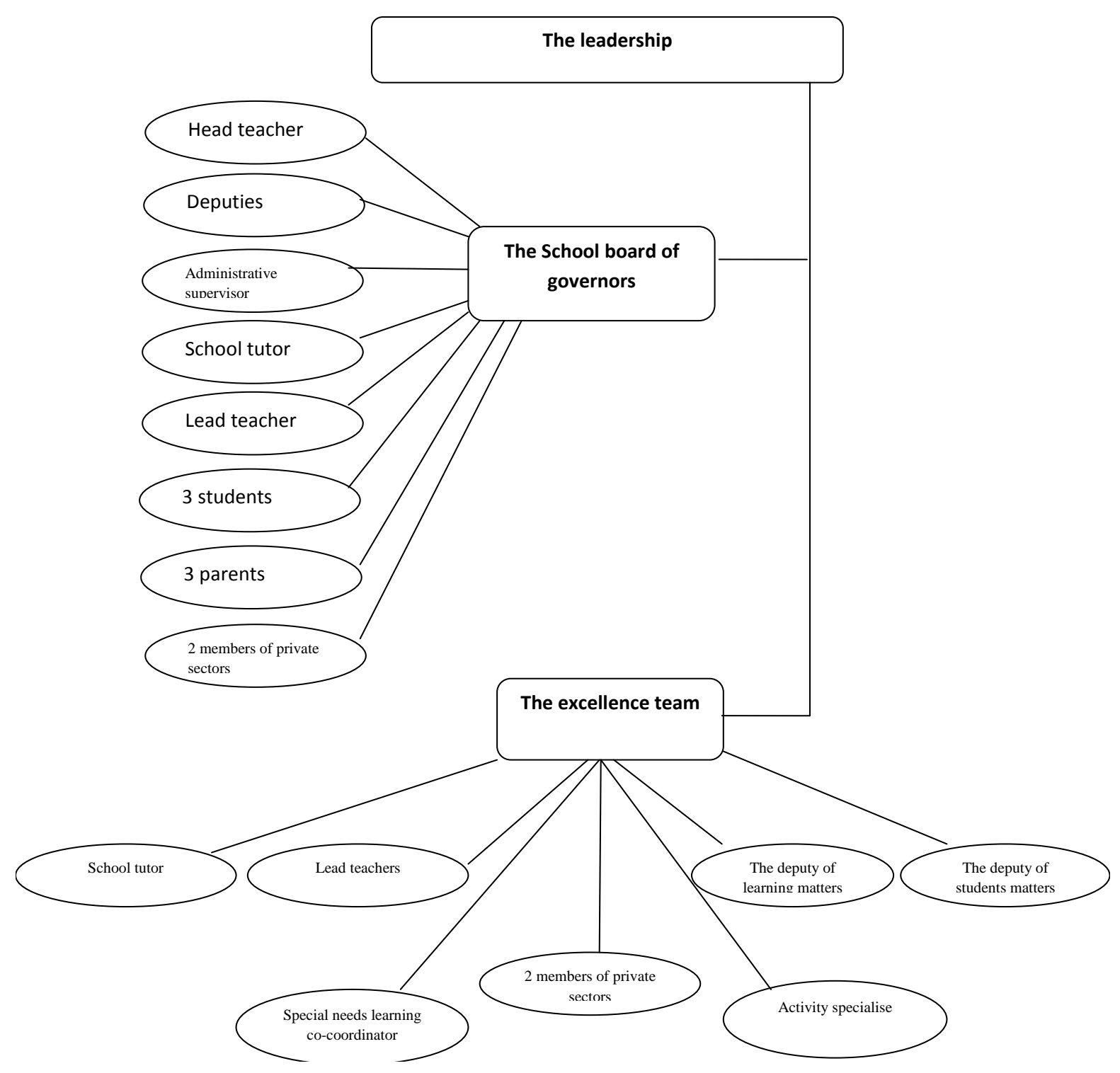

These results might be explained by the fact that any pilot scheme (as in programme one) needs to be modified based on what the reality requests, so programme two was based on the dilemmas that had been faced in programme one.

\subsection{Difficulties}

Human resources: schools need additional members and more incentives to undertake these programmes, but they have a lack of these resources. Evans [26] also argued that teacher's pay system must be related to performance in order to generate motivational impact. However, this system does not occur in Tatweer Schools as the participants reported and criticized.

Provisions: There is a lack of technical provisions for schools in the second phase.

Change resistant: almost $70 \%$ of staff at schools refused the change and resistant it as reported by some participants, some of them transferred to other schools, and they attributed this attitude to consider the change as an additional burden. Moreover, there was an incident of teachers dropping out, which is represented in hiring them by the Educational Department or having vacations in a long- scale. The head teacher did not have authorities to stop hiring teachers from her school. In addition, some teachers do not be able to interact with technology because 
they old or not be motivated. This finding supports the idea of Thomson [16] that careful attention for time provision of teachers' practices has to be considered when schools implement reform. It is also important to consider the culture shift and its implications.

"There was a problem when the programme began in 2007, the culture about Internet was different; there was a fear of using it, some parents did not have Internet at home. As a result, there was a rate of withdrawing of students (50 students out of 360 dropped out from the school); parents refused the idea of having a laptop and Internet with every single student. This was one of the dilemmas, but now most of the students have a smart mobile".

This finding supports the claim of Fidler [17] that the leader "needs to be very aware of the ethos and culture of the school and recognize when it is becoming a handicap to the school change of direction" (p. 270).

\section{Conclusion}

It is believed that giving school more autonomy in its decision -making will lead to school effectiveness and help to achieve the desired goals. It is also important to consider the perceptions of head teachers and teachers about any planned changes for school reform, if they wish to implement it effectively [27], where it did not happen with Tatweer Project.

In terms of autonomy, self-managing school, delegation, devolution and decentralization, all imply power's redistribution within a system of the school, which has been part of the school reform in many countries [28]. These terms have been considered in Saudi educational reform and were represented in Tatweer Schools' system. Tatweer Schools idea brings lessons and experiences can be reviewed and might be useful to consider in the area of schools reform.

\section{Acknowledgement}

I am deeply grateful for Prof. Naz Rassool and Dr Alan Floyd and Prof. Brian Fidler (my previous supervisor) for their support and encouragement during the period of the work; for the Ministry of Education in Saudi Arabia and the Saudi Cultural Bureau in London for making it possible to undertake this wok; for my beloved husband for his support and patience and my lovely children.

\section{References}

[1] Masri, M., Policy process and education reform in the Arab world. Mediterranean Journal of Educational Studies, 2009. 14(1): p. 129-144.

[2] King Abdulla Bin Abdul-Aziz Project for Public Educational Development, 2011. King Abdulla Bin AbdulAziz Project for Public Educational Development, ed. T. Project. Riyadh: King Abdulla Bin Abdul-Aziz Project for Public Educational Development.

[3] Riley, K.A. and K.S. Louis, leadership for change and school reform: international perspectives 2000, USA and Canada Routledge Falmer.

[4] Document of the educational policy of the kingdom of Saudi Arabia. 1970: Saudi Arabia: Riyadh.

[5] Prokop, M., Saudi Arabia: The Politics of Education. In International Affairs (Royal Institute of International Affairs 1944-), 2003. 79(1): p. 77-89.

[6] Mathis, B., Educational leadership: a description of Saudi female principals in the eastern, in Education. 2010, the Faculty of the Graduate College of the Oklahoma State University Oklahoma State

[7] Roy, D.A., Saudi Arabia education: Development policy. Taylor \& Francis, 1992. 28(3): p. 477-508.

[8] Al Rawaf, H. and C. Simmons, The education of women in Saudi Arabia. Comparative Education. Taylor and Francis, Ltd, 1991. 27 (3): p. 287-295.

[9] Alsayqh, N., Authorities of head teachers in decisionmaking in light the regulations: survey, in Umm Alquraa university. 1989, Umm Alquraa university: Makkah.

[10] Muzm, M., The extent of the balance between the responsibilities of school administrators and the level of the powers granted to them in middle school in the city of Riyadh. Athesis. 1997, King Saud University: Riyadh.

[11] Alsahli, M., Comparative study for the reality of head teachers' authorities in public schools: survey. A thesis, in King Abdulaziz University. 2000, King Abdulaziz University: Almadenah Almonawarah.

[12] Alshihri, A., The reality of the practice of head teachers to delegate powers to teachers and its relationship to the achievement of school effectiveness. A thesis, in King khaled University. 2005, King khaled University: Abha.

[13] Alzaidi, A., Job satisfaction among male head teachers in secondary schools in Saudi Arabia, in Newcastle University. 2008a, Newcastle University: Newcastle.

[14] Al-Dhuwaihi, A., New head teachers in Saudi Arabia: Professional identity and learning leadership. A thesis, in University of London. 2011, University of London: London. 
[15] Alzaidi, A., Secondary school head teachers' job satisfaction in Saudi Arabia: the results of a mixed methods approach. ARECLS, 2008b. 5: p. 161-185.

[16] Asfoor, M., Approaches and organisations originality (5th Ed), ed. 5. 1983, Jeddah: Dar Alshrooq.

[17] Albahiri, M., Online CPD for teachers in Saudi Arabia: aptitude, attitudes and barriers. A thesis, in University of Strathclyde. 2010, Strathclyde: Glasgow.

[18] Elmore, R. and W. McLaughlin, Steady Work Policy, Practice, and the Reform of American Education. 1988, California, United States.: RAND Corporation, Santa Monica.

[19] Zamil, S., Define the powers of the school administration: a field study of impediments to delegate some powers of the departments of education to school administrations, in Education. 1998, King Saud University: Riyadh.

[20] Al-Zahrani, M., Directors of education's powers and its role in improving some elements of the educational process, in Education. 1993 Umm Al-Qura University: Mecca.

[21] Patton, M., Qualitative research \& evaluations methods. (3th Ed). 2002 California: Sage.

[22] Robson, C., Real world research: a resource for users of social research methods in applied settings. Third ed. 2011, United Kingdom: John Wiley.

[23] Bryman, A., Social research methods. Fourth ed. 2012, Oxford: Oxford University Press.

[24] Altrichter, H., ed. 'Introduction'. In H. Altrichter \& J. Elliott, Images of educational change. Introduction, ed. H. Altrichter and J. Elliott. 2001, Open University Press: Buckingham. 1-10.

[25] Fidler, B. and M. Edwards, Strategic planning for school improvement. 1996, London: British Educational Management and Administration Society. xxv,268.

[26] Evans, L., Developing teachers in a performance cutlure, in The Performing School: Managing, Teaching, and Learning in a Performance Culture, D. Gleeson and C. Husbands, Editors. 2001, Routledge Falmer: London.

[27] Al-Taneji, S. and L. McLeod, Towards decentralized management in United Arab Emirate (UAE) schools. School effectiveness and school improvement, 2008. 19(3): p. 275-291.

[28] Simkins, T., Autonomy and Accountability, in Choices for self-managing schools: Autonomy and Accountability B. Fidler, Russell, S., and Simkins, T (eds), Editor. 1997, P. Chapman Publication: London. 